\title{
ANALISIS PELAKSANAAN KEWAJIBAN ATAS PAJAK PENGHASILAN PASAL 21 PADA RUMAH SAKIT XYZ
}

\author{
Ni Made Tika Anggreni ${ }^{1}$ \\ Naniek Noviari \\ Fakultas Ekonomi dan Bisnis Universitas Udayana, Bali, Indonesia ${ }^{1,2}$ \\ e-mail: tika_anggreni@yahoo.co.id,/tlp.085737608458
}

\begin{abstract}
The company as a tax cutter has a very large and important role for the government. The company as the income tax cutter must record the tax expense calculation of Article 21 Income Tax in accordance with the rules and procedures for calculating taxes and the results of which will be paid or reported. This study was conducted at XYZ Hospital. The purpose of this research is to analyze the implementation of the obligation for income tax article 21 whether it in accordance with the Act. This study uses qualitative research methods, with a case study approach method. The data used are employee salary data and reporting of PPH 21 period XYZ Hospital in 2017. The results of this study indicate that the calculations performed by XYZ Hospital are correct, but for the depositing and reporting of Article 21 Income Tax that has been applied by XYZ Hospital yet in accordance with the Act so that it causes the existence of contingency obligations that must be repaid.
\end{abstract}

Keywords: Obligations; Article 21 Income Tax; Hospital.

\begin{abstract}
ABSTRAK
Perusahaan sebagai pemotong pajak memiliki peranan yang sangat besar dan penting bagi pemerintah. Perusahaan sebagai pemotong pajak penghasilan wajib membuat pencatatan atas penghitungan beban pajak $\mathrm{PPh}$ Pasal 21 sesuai dengan peraturan dan tata cara penghitungan pajak dan hasilnya nantinya itulah yang akan dibayarkan atau dilaporkan. Penelitian ini dilaksanakan di Rumah Sakit XYZ. Tujuan penelitian ini dilakukan yaitu untuk menganalisis pelaksanaan kewajiban atas pajak penghasilan pasal 21 apakah telah sesuai dengan Undang-Undang. Penelitian ini menggunakan metode penelitian kualitatif, dengan metode pendekatan studi kasus. Data yang digunakan data gaji karyawan dan pelaporan SPT masa PPh 21 Rumah Sakit XYZ tahun 2017. Hasil dari penelitian ini menunjukkan bahwa perhitungan yang dilakukan oleh Rumah Sakit XYZ sudah benar, tetapi untuk penyetoran dan pelaporan PPh Pasal 21 yang telah diterapkan oleh Rumah Sakit XYZ belum sesuai dengan Undang - Undang sehingga menyebabkan adanya kewajiban kontijensi yang harus dilunasi.
\end{abstract}

Kata kunci: Obligasi; Pasal 21 Pajak Penghasilan; Rumah Sakit. 


\section{PENDAHULUAN}

Pajak mempunyai peranan yang sangat penting dalam kehidupan bernegara, khususnya di dalam pelaksanaan pembangunan karena pajak merupakan sumber pendapatan negara untuk membiayai semua pengeluaran termasuk pengeluaran pembangunan. Pajak adalah iuran rakyat kepada kas negara berdasarkan undang-undang (yang dapat dipaksakan)dengan tiada mendapatkan jasa timbal (kontraprestasi) yang langsung dapat ditunjukkan dan yang digunakan untuk membayar pengeluaran negara (Mardiasmo, 2016:1). Pajak merupakan penyumbang pendapatan negara yang terbesar bagi perekonomian Negara. Di Indonesia pada APBN 2017 menunjukkan bahwa penerimaan negara yang berasal dari pajak sebesar $85,6 \%$ dari total pendapatan negara. Penerimaan perpajakan dalam APBN 2017 ditetapkan sebesar Rp 1498, 9 triliun atau meningkat rata - rata sebesar 11,3\% dari tahun sebelumnya. Pajak Penghasilan dalam APBN 2017 memberikan kontribusi terbesar terhadap Penerimaan Perpajakan sebesar 52, 6\% atau sebesar 787,7 triliun rupiah. Pajak Penghasilan 21 memberikan kontribusi sebesar 148,5 triliun rupiah, terbesar ketiga setelah penerimaan PPh Final dan Fiskal dan PPh 25/29 Badan.

Saat ini sistem pemungutan pajak di Indonesia menganut dua sistem, yaitu self assessment system dan with holding system. Self assessment system adalah sistem pemungutan pajak dimana Wajib Pajak orang pribadi maupun badan diberi wewenang dan kepercayaan untuk menghitung, memperhitungkan, menyetorkan, dan melaporkan pajak yang terutang kepada negara sedangkan withholding tax system adalah sistem pemungutan pajak yang perhitungan 
besarnya pajak terutang poleh Wajib Pajak dilakukan oleh pihak ketiga (Krupsky, 2005). Dalam withholding tax system pemungutan pajak yang dilakukan oleh pihak ketiga diberikan kepercayaan untuk melaksanakan kewajiban memotong atau memungut pajak atas penghasilan seseorang atau badan.

Withholding tax system selain memperlancar masuknya dana ke kas Negara tanpa intervensi fiskus juga dapat menghemat biaya administrasi pemungutan (administrative cost), seperti pada self assessment, wajib pajak yang dipotong atau dipungut pajaknya secara tidak terasa telah memenuhi kewajiban perpajakannya. Manfaat withholding tax system antara lain, dapat meningkatkan kepatuhan secara sukarela karena pembayar pajak secara tidak langsung telah membayar pajaknya, pengumpulan pajak secara otomatis bagi pemerintah tanpa mengeluarkan biaya, meningkatkan penerimaan pajak (optimalisasi perluasan objek pajak), merupakan penerapan prinsip convenience of tax system, serta meningkatkan penerimaan pajak (optimalisasi perluasan obyek pajak). Namun demikian, peran pengawasan DJP tetap perlu dilakukan untuk memastikan jumlah pajak yang dibayarkan oleh Wajib Pajak sudah sesuai dengan jumlah yang seharusnya.

Jika Wajib Pajak patuh dalam menjalankan kewajiban sesuai undangundang dan peraturan perpajakan, maka akan berdampak positif bagi perusahaan itu sendiri. Potensi sanksi denda, bunga dan kurang bayar tambahan pun dapat dikurangi. Untuk itu kepatuhan perpajakan dari perusahaan menjadi 
hal yang harus diperhatikan dengan baik agar tidak timbul kewajiban kontijensi (kewajiban yang akan timbul di masa sekarang) akibat ketidakpatuhan dan kelalaian perusahaan dalam kewajiban perpajakan. Perusahaan sebagai pemotong pajak memiliki peranan yang sangat besar dan penting bagi pemerintah. Perusahaan sebagai pemotong pajak penghasilan adalah wajib membuat pencatatan atas penghitungan beban pajak PPh Pasal 21 sesuai dengan peraturan dan tata cara penghitungan pajak dan hasilnya itulah yang akan dibayarkan atau dilaporkan. Akan tetapi fenomena yang terjadi masih terdapat perusahaan yang melaksanakan penghitungan pajak tidak sesuai dengan ketentuan yang berlaku. Hal ini disebabkan perusahaan beranggapan bahwa pajak sebagai biaya sehingga perusahaan meminimalkan biaya dan lebih mengoptimalkan laba. Selain itu masih juga terdapat selisih dalam penhitungan pajak bahkan ada perusahaan yang berusaha memperkecil berusaha memperkecil jumlah pajaknya atau menggelapkan pajak dan hal ini jelas tindakan kriminal yang merugikan negara. Perusahaan yang telah diberikan wewenang pemotongan pajak diharapkan dapat bekerjasama dala memotong pajak ataupun dalam melaporkan pajak sesuai dengan peraturan perjakan sehingga pelanggaran hukum seperti penyelewengan dan penipuan terhadap pajak tidak terjadi. Dengan adanya kepatuhan dalam memotong dan melaporkan pajak maka perusahaan dapat membantu meninkatkan pendapatan negara dan mendukung pembangunan nasional.

Industri rumah sakit adalah industri yang padat karya dan padat modal. Padat karya ditandai dengan banyaknya tenaga kerja yang terlibat dalam aktivitas 
rumah sakit, padat modal bisa dilihat dari aktiva rumah sakit berupa peralatan medis yang nilainya sangat material dan juga persediaan obat dengan perputaran yang tinggi. Padat tenaga kerja disini dimaksudkan tidak hanya pegawai tetap yang mengelola operasional rumah sakit tetapi juga termasuk tenaga ahli yaitu dokter - dokter yang berpraktek di rumah sakit. Sehingga perhitungan $\mathrm{PPh} 21$ menjadi lebih kompleks karena terdiri dari pegawai tetap yang mengelola operasional rumah sakit dan juga tenaga ahli yaitu dokter. Rumah Sakit XYZ yang dikelola oleh PT. XYZ merupakan salah satu Rumah Sakit yang mengkhususkan perawatan Ibu dan Anak yang berlokasi di Denpasar, Bali. Rumah Sakit XYZ selama ini melakukan kewajiban perpajakannya dengan self assessment system. Self assessment system merupakan sistem pemungutan pajak yang memberi wewenang kepada Wajib Pajak untuk menentukan sendiri besarnya pajak terutang berdasarkan peraturan perpajakan yang berlaku dengan kata lain, wajib pajak merupakan pihak yang berperan aktif dalam menghitung, membayar, dan melaporkan besaran pajaknya ke Kantor Pelayanan Pajak (KPP). Pada tahun 2017 Rumah Sakit XYZ pernah mendapatkan Surat Tagihan Pajak (STP) PPh 21 dikarenakan keterlambatan dalam penyetoran PPh 21 untuk masa pajak September sampai Desember 2016, sehingga harus membayar sanksi bunga karena keterlamabatan pembayaran. Penelitian ini dilakukan untuk memastikan apakah kewajiban perpajakan Rumah Sakit XYZ sudah dilakukan dengan benar dan untuk mengetahui sanksi yang mungkin muncul di masa mendatang.

Tujuan penelitian ini adalah untuk menganalisis dan menilai bagaimana kepatuhan perpajakan Rumah Sakit XYZ selama tahun 2017 dan juga untuk 
mengetahui apakah terdapat kewajiban kontijen oleh Rumah Sakit XYZ dimasa depan. Penelitian ini diharapkan dapat memberikan gambaran, wawasan yang lebih luas mengenai penerapan tax review atas pajak penghasilan pasal 21. Selain itu, penelitian ini juga dapat digunakan sebagai bahan masukan untuk peneliti lain yang melakukan penelitian dalam ruang lingkup yang sama, serta dapat dijadikan sebagai perbandingan, pengembangan, dan penyempurnaan dari penelitian-penelitian yang telah dilakukan sebelumnya serta diharapkan dapat memberikan masukan-masukan, sumbangan pemikiran dan bahan pertimbangan mengenai pelaksanaan kewajiban atas pajak penghasilan pasal 21 agar dapat menjadi bahan evaluasi di masa akan datang oleh pihak pembuat kebijakan, khususnya yang berhubungan dengan pajak.

Penelitian mengenai penghitungan, pemotongan dan pelaporan pajak penghasilan pasal 21 sebelumnya yang dilakukan oleh Jeane Susan (2013) berjudul "Analisis Perhitungan Pajak Penghasilan Pasal 21 pada PT. Megasurya Nusalestari Manado." Dari hasil penelitiannya menunjukkan bahwa PT. Megasurya Lestari dalam melakukan penghitungan Pajak Penghasilan Pasal 21 sudah sesuai dengan Undang-Undang No. 36 Tahun 2008 akan tetapi masih juga didapatkan kesalahan-kesalahan dalam perhitungan. Selain itu penelitian lain dilakukan oleh Meyliza Dalughu (2015) yang berjudul “Analisis Perhitungan Dan Pemotongan PPh Pasal 21 Pada Karyawan PT BPR Primaesa Sejahtera Manado.” Penelitiannya mengatakan bahwa perhitungan dan pemotongan PPh Pasal 21 yang telah diterapkan juga telah sesuai dengan Undang-Undang No. 36 Tahun 2008 tentang pajak penghasilan. Menurut Herduard R.Homenta (2015) dalam 
penelitiannya yang berjudul “Analisis Perhitungan, Pemotongan, Pencatatan, Dan Pelaporan Pajak Penghasilan Pasal 21 Pada CV. Multi Karya Utama”, menunjukkan bahwa CV. Multi Karya Utama juga telah melaksanakan perhitungan PPh Pasal 21 yang dipotong pada para karyawan dan telah sesuai dengan UU No. 36 Tahun 2008 tentang Pajak Penghasilan. Setelah melakukan pemotongan maka dilakukan pencatatan untuk menghindari kesalahan.

\section{METODE PENELITIAN}

Penelitian ini digunakan jenis penelitian kualitatif dengan metode pendekatan studi kasus. Penelitian kualitatif menurut Sugiyono (2013:14) adalah metode yang berlandaskan pada filsafat pospositivisme, digunakan untuk meneliti pada kondisi obyek yang alamiah, dimana penulis adalah sebagai instrumen kunci, pengambilan sampel sumber data dilakukan secara purposive dan snowball, teknik pengumpulan dengan tringgulasi (gabungan), analisis data bersifat induktif/kualitatif, dan hasil penelitian kualitatif lebih menekankan makna dari pada generalisasi. Metode penelitian kualitatif juga merupakan metode penelitian yang lebih menekankan pada aspek pemahaman secara mendalam terhadap suatu masalah dari pada melihat permasalahan untuk penelitian generalisasi. Metode yang digunakan dalam penelitian ini adalah studi kasus dimana peneliti berusaha untuk mengetahui apakah kewajiban perpajakan Rumah Sakit XYZ sudah berjalan sesuai dengan aturan yang berlaku. Metode penelitian studi kasus meneliti suatu kasus atau fenomena tertentu yang ada dalam masyarakat yang dilakukan secara mendalam untuk mempelajari latar belakang, keadaan, dan interaksi yang terjadi. 
Objek penelitian dalam penelitian ini adalah Pajak Penghasilan Pasal 21 pada Rumah Sakit XYZ tahun pajak 2017. Definisi operasional dalam penelitian adalah tax review dan pajak penghasilan pasal 21 . Teknik pengumpulan data yang digunakan dalam penelitian ini adalah dokumentasi dan wawancara. Dokumentasi dari penelitian ini meliputi data gaji karyawan selama tahun 2017, data status karyawan, data NPWP karyawan, Rekapan SPT Masa PPh 21, serta tanda terima SPT Masa PPh 21. Wawancara yaitu mengadakan tanya jawab dengan staf yang ditujukan untuk mengadakan penilaian tentang perhitungan dan pelaporan Pajak Penghasilan Pasal 21 pada Rumah Sakit XYZ.

Teknik analisis data yang digunakan adalah teknik analisis kualitatif dengan pendekatan studi kasus. Penelitian dilakukan dengan melakukan review laporan gaji Rumah Sakit XYZ tahun pajak 2017. Tax review dilakukan dengan menggunakan data gaji karyawan dan pelaporan SPT masa PPh 21 Rumah Sakit XYZ tahun 2017. Hal yang dilakukan terlebih dahulu adalah mengumpulkan data dan informasi mengenai penghasilan pegawai Rumah Sakit XYZ tahun 2017, informasi kebijakan perusahaan tentang pemberian gaji, jamsostek, dan THR kepada karyawan dan menentukan status karyawan dan PTKP untuk dijadikan sebagai dasar perhitungan $\mathrm{PPh}$ Pasal 21. Perhitungan PPh Pasal 21 karyawan sesuai dengan ketentuan perpajakan dengan memeriksa Surat Setoran Pajak (SSP) dan SPT Masa PPh Pasal 21 untuk mengetahui ketepatan perhitungan dan ketepatan waktu pembayaran dan menghitung kurang bayar yang mungkin timbul akibat kesalahan perhitungan PPh Pasal 21. Langkah - langkah analisis data dalam 
penelitian ini adalah yang pertama menelaah biaya-biaya yang menjadi objek pemotongan pajak PPh 21 di rumah sakit XYZ, menelaah ketepatan objek pemotongan, tarif pemotongan, serta perhitungan pajak yang dilakukan rumah sakit XYZ kemudian meneliti bukti pemotongan dan SPT Masa PPh 21 untuk meyakinkan keabsahan dokumen yang berkaitan serta ketepatan perhitungan serta ketepatan waktu dalam melakukan penyetoran dan pelaporan SPT Masa PPh 21.

\section{HASIL DAN PEMBAHASAN}

Objek Pajak PPh Pasal 21 untuk Rumah Sakit XYZ terdiri dari pihak internal dan eksternal. Pemotongan dari pihak internal hanya berasal dari pegawai tetap perusahaan, sedangkan pihak eksternal berasal dari tenaga ahli yang berkontribusi memberikan jasa untuk menunjang operasional Rumah Sakit XYZ. Berdasarkan data yang diperoleh dari Rumah Sakit XYZ, maka dapat dijabarkan objek PPh 21 Rumah Sakit XYZ sebagai berikut : 1). Pihak Internal, Objek PPh 21 berupa penghasilan bruto yang diberikan secara teratur dan tidak teratur setiap bulannya kepada pegawai tetap. Penghasilan untuk pegawai tersebut terdiri atas gaji, berbagai tunjangan, bonus, BPJS, dan Biaya Pensiun. 2). Pihak Eksternal, Objek PPh 21 diberikan kepada tenaga ahli. Tenaga ahli yang termasuk disini adalah dokter dan juga konsultan.

Dalam pengenaan tarif pajak PPh 21, Rumah Sakit XYZ menggunakan tarif sesuai dengan pasal 17 ayat 1 UU Pajak Penghasilan. PPh Pasal 21 yang dipotong oleh Pemotong PPh Pasal 21 untuk setiap masa pajak wajib disetor ke Kantor Pos atau Bank yang ditunjuk oleh Kementerian Keuangan, yang paling 
lama 10 (sepuluh) hari setelah masa pajak berakhir. Berikut adalah daftar penyetoran yang dilakukan oleh Rumah Sakit XYZ selama masa Januari hingga Desember 2017.

Tabel 1.

Penyetoran Masa SPT PPh 21 Rumah Sakit XYZ Tahun 2017

\begin{tabular}{|c|c|}
\hline SPT Masa & $\begin{array}{c}\text { Tanggal } \\
\text { Penyetoran RS } \\
\text { XYZ }\end{array}$ \\
\hline Januari 2017 & 12 Oktober 2017 \\
\hline Februari 2017 & 03 November 2017 \\
\hline Maret 2017 & 14 Desember 2017 \\
\hline April 2017 & 08 Januari 2018 \\
\hline Mei 2017 & 16 Januari 2018 \\
\hline Juni 2017 & 26 Februari 2018 \\
\hline Juli 2017 & 22 Maret 2018 \\
\hline Agustus 2017 & 06 April 2018 \\
\hline September 2017 & 19 April 2018 \\
\hline Oktober 2017 & 08 Juni 2018 \\
\hline November 2017 & 15 Agustus 2018 \\
\hline Desember 2017 & 03 Oktober 2018 \\
\hline
\end{tabular}

Sumber: Rumah Sakit XYZ, 2018

SPT PPh 21 dilaporkan maksimal pada tanggal 20 setelah masa pajak berakhir dan jika bertepatan hari libur dapat dilakukan di hari berikutnya. SPT masa ini dilaporkan lengkap dengan cap dan tanda tangan direktur Rumah Sakit dan dilampirkan bukti bayar. Berikut ini adalah daftar pelaporan SPT PPh Pasal 21 yang dilakukan oleh Rumah Sakit XYZ selama masa Januari hingga Desember 2017. 
Tabel 2.

Pelaporan Masa SPT PPh 21 Rumah Sakit XYZ Tahun 2017

\begin{tabular}{ll}
\hline \multicolumn{1}{c}{ SPT Masa } & \multicolumn{1}{c}{$\begin{array}{c}\text { Tanggal Pelaporan } \\
\text { RS XYZ }\end{array}$} \\
\hline Januari 2017 & 18 Oktober 2017 \\
Februari 2017 & 30 November 2017 \\
Maret 2017 & 19 Januari 2018 \\
April 2017 & 19 Januari 2018 \\
Mei 2017 & 19 Januari 2018 \\
Juni 2017 & 28 Februari 2018 \\
Juli 2017 & 24 Maret 2018 \\
Agustus 2017 & 20 April 2018 \\
September 2017 & 20 April 2018 \\
Oktober 2017 & 25 Juli 2018 \\
November 2017 & 20 Agustus 2018 \\
Desember 2017 & 03 Oktober 2018 \\
\hline Sumber: Rumah Sakit XYZ 2018 &
\end{tabular}

Sumber: Rumah Sakit XYZ, 2018

Untuk menganalisis kewajiban atas pajak penghasilan pasal 21 dapat dilihat dari berbagai jenis objek pajak terkait transaksi Rumah Sakit XYZ dengan pihak internal maupun eksternal. Secara umum objek PPh pasal 21 yang dipotong oleh Rumah Sakit XYZ sudah sesuai dengan objek pajak yang diatur dalam Peraturan Direktur Jenderal Pajak Nomor PER-16/PJ/2016 tentang Pedoman Teknis Tata Cara Pemotongan, Penyetoran, dan Pelaporan PPh Pasal 21/26 Sehubungan dengan Pekerjaan, Jasa, dan Kegiatan Orang Pribadi. Untuk pengenaan tarif pajak PPh 21, Rumah Sakit XYZ menggunakan tarif sesuai dengan pasal 17 ayat 1 UU Pajak Penghasilan. Hal ini dibuktikan melalui penelaahan SPT Masa PPh 21 dari bulan Januari hingga Desember 2017. Untuk dasar pengenaan pajak dari tiap objek pajak tergantung subjek yang diberikan penghasilan oleh Rumah Sakit XYZ.

Dasar pengenaan Pajak terkait PPh 21 ini sudah sesuai dengan Peraturan Direktur Jenderal Pajak Nomor PER-16/PJ/2016 dengan ketentuan 
sebagai berikut: 1). Dasar Pengenaan Pajak (DPP) 50\% dari jumlah penghasilan bruto yang berlaku bagi bukan pegawai sebagaimana dimaksud dalam Peraturan Direktur Jenderal Pajak No. PER-32/PJ/2015 Pasal 3 huruf c yang menerima imbalan yang tidak bersifat berkesinambungan. 2). Dasar Pengenaan Pajak (DPP) untuk jumlah penghasilan bruto yang berlaku bagi penerima penghasilan selain penerima penghasilan di atas. 3). Dasar Pengenaan Pajak (DPP) dan Pemotongan PPh Pasal 26 adalah jumlah penghasilan bruto.

Rumah Sakit XYZ hanya menyetorkan sejumlah uang yang sesuai dengan perhitungan SPT yang dilakukan oleh Konsultan Pajak. Penyetoran pajak PPh 21 seharusnya dilakukan oleh Pegawai Rumah Sakit XYZ paling lambat tanggal 10 setiap bulannya. Tetapi dari data yang diperoleh dari Rumah Sakit XYZ ditemukan adanya keterlambatan dalam penyetoran PPh Pasal 21 dari masa Januari - Desember 2017. Berikut adalah analisa untuk penyetoran

SPT PPh 21 Rumah Sakit XYZ.

Tabel 3.

Analisa Penyetoran Masa SPT PPh 21 Rumah Sakit XYZ Tahun 2017

\begin{tabular}{llll}
\hline \multicolumn{1}{c}{ SPT Masa } & \multicolumn{1}{c}{$\begin{array}{c}\text { Tanggal } \\
\text { Penyetoran Sesuai } \\
\text { Aturan }\end{array}$} & $\begin{array}{c}\text { Tanggal } \\
\text { Penyetoran RS } \\
\text { XYZ }\end{array}$ & Analisa \\
\hline Januari 2017 & 10 Februari 2017 & 12 Oktober 2017 & Terlambat Bayar \\
Februari 2017 & 10 Maret 2017 & 03 November 2017 & Terlambat Bayar \\
Maret 2017 & 10 April 2017 & 14 Desember 2017 & Terlambat Bayar \\
April 2017 & 10 Mei 2017 & 08 Januari 2018 & Terlambat Bayar \\
Mei 2017 & 10 Juni 2017 & 16 Januari 2018 & Terlambat Bayar \\
Juni 2017 & 10 Juli 2017 & 26 Februari 2018 & Terlambat Bayar \\
Juli 2017 & 10 Agustus 2017 & 22 Maret 2018 & Terlambat Bayar \\
Agustus 2017 & 10 September 2017 & 06 April 2018 & Terlambat Bayar \\
\hline
\end{tabular}

Bersambung 
ISSN : 2337-3067

E-Jurnal Ekonomi dan Bisnis Universitas Udayana 9.1 (2020):39-56

Lanjutan

Tabel 3.

Analisa Penyetoran Masa SPT PPh 21 Rumah Sakit XYZ Tahun 2017

\begin{tabular}{rccr}
\hline SPT Masa & $\begin{array}{c}\text { Tanggal } \\
\text { Penyetoran Sesuai } \\
\text { Aturan }\end{array}$ & $\begin{array}{c}\text { Tanggal } \\
\text { Penyetoran RS } \\
\text { XYZ }\end{array}$ & Analisa \\
\hline September 2017 & 10 Oktober 2017 & 19 April 2018 & Terlambat Bayar \\
Oktober 2017 & 10 November 2017 & 08 Juni 2018 & Terlambat Bayar \\
November 2017 & 10 Desember 2017 & 15 Agustus 2018 & Terlambat Bayar \\
Desember 2017 & 10 Januari 2017 & 03 Oktober 2018 & Terlambat Bayar
\end{tabular}

Sumber: Rumah Sakit XYZ (Data diolah, 2018)

Pada daftar penyetoran dapat dilihat terjadi keterlambatan di setiap bulannya di Tahun 2017. Atas keterlambatan tersebut, Rumah Sakit XYZ seharusnya dikenakan sanksi bunga $2 \%$ setiap bulannya untuk setiap keterlambatan penyetoran. SPT PPh 21 dilaporkan maksimal pada tanggal 20 setelah masa pajak berakhir dan jika bertepatan hari libur dapat dilakukan di hari berikutnya.

Pelaporan SPT masa PPh 21 Rumah Sakit XYZ seharusnya dilakukan oleh Konsultan Pajak tiap bulannya. SPT masa ini dilaporkan lengkap dengan cap dan tanda tangan direktur Rumah Sakit dan dilampirkan bukti bayar. Tetapi karena adanya keterlambatan penyetoran PPh 21 maka untuk pelaporan SPT PPh 21 juga terjadi keterlambatan. Berikut adalah analisa untuk pelaporan SPT PPh 21 Rumah Sakit XYZ. 
Tabel 4.

Analisa Pelaporan Masa SPT PPh 21 Rumah Sakit XYZ Tahun 2017

\begin{tabular}{llll}
\hline \multicolumn{1}{c}{ SPT Masa } & \multicolumn{1}{c}{$\begin{array}{c}\text { Tanggal } \\
\text { Pelaporan Sesuai } \\
\text { Aturan }\end{array}$} & $\begin{array}{c}\text { Tanggal } \\
\text { Pelaporan RS XYZ }\end{array}$ & Analisa \\
\hline Januari 2017 & 20 Februari 2017 & 18 Oktober 2017 & Terlambat lapor \\
Februari 2017 & 20 Maret 2017 & 30 November 2017 & Terlambat lapor \\
Maret 2017 & 20 April 2017 & 19 Januari 2018 & Terlambat lapor \\
April 2017 & 20 Mei 2017 & 19 Januari 2018 & Terlambat lapor \\
Mei 2017 & 20 Juni 2017 & 19 Januari 2018 & Terlambat lapor \\
Juni 2017 & 20 Juli 2017 & 28 Februari 2018 & Terlambat lapor \\
Juli 2017 & 20 Agustus 2017 & 24 Maret 2018 & Terlambat lapor \\
Agustus 2017 & 20 September 2017 & 20 April 2018 & Terlambat lapor \\
September 2017 & 20 Oktober 2017 & 20 April 2018 & Terlambat lapor \\
Oktober 2017 & 20 November 2017 & 25 Juli 2018 & Terlambat lapor \\
November 2017 & 20 Desember 2017 & 20 Agustus 2018 & Terlambat lapor \\
Desember 2017 & 20 Januari 2017 & 03 Oktober 2018 & Terlambat lapor \\
\hline
\end{tabular}

Sumber: Rumah Sakit XYZ (Data diolah, 2018)

Setelah dilakukan pengumpulan data pelaporan SPT PPhP21PRumahPSakit XYZ selama tahun 2017, rumah sakit XYZ selalu terlambat dalam melaporkan SPT masa PPh 21. Dengan adanya keterlambatan tersebut maka akan muncul sanksi denda akibat terlambat melapor sebesar Rp 100.000 setiap bulannya. Untuk kewajiban perpajakan terkait PPh Pasal 21 masa tahun 2017 telah dilaksanakan sesuai Undang-undang Perpajakan oleh Rumah Sakit XYZ. Objek dan Tarif PPh 21 yang dipotong oleh Rumah Sakit XYZ sudah sesuai dengan Peraturan Direktur Jenderal Pajak Nomor PER-16/PJ/2016 tentang Pedoman Teknis Tata Cara Pemotongan, penyetoran, dan Pelaporan PPh Pasal 21/26 Sehubungan dengan Pekerjaan, Jasa, dan Kegiatan Orang Pribadi. Sedangkan untuk Penyetoran dan Pelaporan PPh 21 Rumah Sakit XYZ, walaupun sudah dilakukan penyetoran dan pelaporan tetapi terdapat 
keterlambatan setiap bulannya. Setelah dilakukan penelitian, terdapat kewajiban kontijensi seperti sanksi bunga dan denda yang harus dibayarkan oleh Rumah Sakit XYZ akibat adanya keterlambatan penyetoran dan pelaporan PPh 21. Atas keterlambatan penyetoran tersebut, Rumah Sakit XYZ seharusnya dikenakan sanksi bunga $2 \%$ setiap bulannya untuk setiap keterlambatan penyetoran. Berikut rincian sanksi bunga terkait PPh 21 Rumah Sakit XYZ yang harus dibayarkan jika Surat Tagihan Pajak dilayangkan oleh KPP setempat.

Tabel 5.

Analisa Perhitungan Sanksi Bunga PPh 21 Rumah Sakit XYZ Tahun 2017 (Dalam Rupiah) - 1

\begin{tabular}{ccccccc}
\hline SPT Masa & Pembetulan & $\begin{array}{c}\text { Tanggal } \\
\text { Bayar }\end{array}$ & $\begin{array}{c}\text { PPh 21 } \\
\text { yang } \\
\text { Harus } \\
\text { Dibayar }\end{array}$ & $\begin{array}{c}\text { Sanksi } \\
\text { Bunga }\end{array}$ & $\begin{array}{c}\text { Kurun } \\
\text { Waktu }\end{array}$ & $\begin{array}{c}\text { Total Sanksi } \\
\text { Bunga }\end{array}$ \\
\hline $\begin{array}{c}\text { Januari } \\
2017\end{array}$ & 0 & $\begin{array}{c}12 \text { Oktober } \\
2017\end{array}$ & 6.126 .165 & $2 \%$ & 9 bulan & 1.102 .709 \\
Februari & 03 & November \\
2017 & 0 & 2017 & 4.722 .732 & $2 \%$ & 8 bulan & 755.637 \\
\hline Sumber: Rumah Sakit XYZ
\end{tabular}

Sumber: Rumah Sakit XYZ (Data diolah, 2018)

Tabel 6.

Analisa Perhitungan Sanksi Bunga PPh 21 Rumah Sakit XYZ Tahun 2017 (Dalam Rupiah) - 2

\begin{tabular}{ccccccc}
\hline SPT Masa & Pembetulan & Tanggal Bayar & $\begin{array}{c}\text { PPh 21 yang } \\
\text { Harus } \\
\text { Dibayar }\end{array}$ & $\begin{array}{c}\text { Sanksi } \\
\text { Bunga }\end{array}$ & $\begin{array}{c}\text { Kurun } \\
\text { Waktu }\end{array}$ & $\begin{array}{c}\text { Total Sanksi } \\
\text { Bunga }\end{array}$ \\
\hline Maret 2017 & 0 & 14 Desember 2017 & 7.601 .848 & $2 \%$ & 9 bulan & 1.368 .332 \\
April 2017 & 0 & 08 Januari 2018 & 6.479 .284 & $2 \%$ & 8 bulan & 1.036 .685 \\
Mei 2017 & 0 & 16 Januari 2018 & 4.313 .213 & $2 \%$ & 8 bulan & 690.114 \\
Juni 2017 & 0 & 26 Februari 2018 & 5.483 .059 & $2 \%$ & 8 bulan & 877.289 \\
Juli 2017 & 0 & 22 Maret 2018 & 6.677 .349 & $2 \%$ & 8 bulan & 1.068 .376 \\
\hline
\end{tabular}


Lanjutan

Tabel 6.

Analisa Perhitungan Sanksi Bunga PPh 21 Rumah Sakit XYZ Tahun 2017 (Dalam Rupiah) - 2

\begin{tabular}{lcccccc}
\hline SPT Masa & Pembetulan & Tanggal Bayar & $\begin{array}{r}\text { PPh 21 } \\
\text { yang } \\
\text { Harus } \\
\text { Dibayar }\end{array}$ & $\begin{array}{c}\text { Sanksi } \\
\text { Bunga }\end{array}$ & $\begin{array}{c}\text { Kurun } \\
\text { Waktu }\end{array}$ & $\begin{array}{c}\text { Total Sanksi } \\
\text { Bunga }\end{array}$ \\
\hline $\begin{array}{l}\text { Agustus } \\
2017\end{array}$ & 0 & 06 April 2018 & 8.239 .470 & $2 \%$ & 7 bulan & 1.153 .525 \\
$\begin{array}{l}\text { September } \\
2017\end{array}$ & 0 & 19 April 2018 & 8.197 .915 & $2 \%$ & 7 bulan & 1.147 .708 \\
& & & & & \\
Oktober \\
2017
\end{tabular}

Sumber: Rumah Sakit XYZ (Data diolah, 2018)

Dari Tabel 6, dapat disimpulkan bahwa sanksi bunga Rumah Sakit XYZ selama tahun 2017 adalah sebesar Rp 16.771.122. Jumlah ini merupakan hasil penjumlahan sanksi bunga akibat keterlambatan pembayaran pajak yang dilakukan. Sedangkan untuk keterlambatan Pelaporan PPh 21, Rumah Sakit XYZ dikenakan denda akibat terlambat melapor sebesar Rp 100.000 setiap bulannya. Berikut rincian sanksi denda terkait PPh 21 Rumah Sakit XYZ yang harus dibayarkan jika Surat Tagihan Pajak dilayangkan oleh KPP setempat. 
Tabel 7.

Analisa Perhitungan Sanksi Denda PPh 21 Rumah Sakit XYZ Tahun 2017 (Dalam Rupiah)

\begin{tabular}{lcll}
\hline SPT Masa & Pembetulan & Tanggal Lapor & Sanksi Denda \\
\hline Januari 2017 & 0 & 12 Oktober 2017 & 100.000 \\
Februari 2017 & 0 & 03 November 2017 & 100.000 \\
Maret 2017 & 0 & 14 Desember 2017 & 100.000 \\
April 2017 & 0 & 08 Januari 2018 & 100.000 \\
Mei 2017 & 0 & 16 Januari 2018 & 100.000 \\
Juni 2017 & 0 & 26 Februari 2018 & 100.000 \\
Juli 2017 & 0 & 22 Maret 2018 & 100.000 \\
Agustus 2017 & 0 & 06 April 2018 & 100.000 \\
September 2017 & 0 & 19 April 2018 & 100.000 \\
Oktober 2017 & 0 & 08 Juni 2018 & 100.000 \\
November 2017 & 0 & 15 Agustus 2018 & 100.000 \\
Desember 2017 & 0 & 03 Oktober 2018 & 100.000 \\
TOTAL & & & 1.200 .000
\end{tabular}

Sumber: Rumah Sakit XYZ (Data diolah, 2018)

Dengan adanya keterlambatan pelaporan maka sanksi denda yang akan diterima oleh Rumah Sakit XYZ selama tahun 2017 adalah 1.200.000.

\section{SIMPULAN}

Berdasarkan analisis data dan pembahasan yang telah dilakukan sebelumnya, dapat disimpulkan selama tahun 2017 kepatuhan Rumah Sakit XYZ atas pelaksanaan kewajiban atas pajak penghasilan pasal 21 adalah kurang baik. Terjadi keterlambatan pelaporan dan penyetoran pajak penghasilan PPh 21 selama tahun 2017 di setiap masanya. Rumah Sakit XYZ memiliki kewajiban kontijensi yang harus dilunasi yaitu sanksi bunga dan denda akibat adanya keterlamabatan penyetoran dan pelaporan pajak penghasilan PPh 21.

Berdasarkan hasil penelitian dan simpulan di atas, adapun saran yang dapat diberikan kepada Rumah Sakit XYZ yaitu sebaiknya Rumah Sakit 
XYZ dalam menghitung Pajak PPh 21 menggunakan metode Gross. Metode Gross adalah metode pemotongan pajak dimana karyawan menanggung sendiri jumlah pajak penghasilannya. Selama ini Rumah Sakit XYZ menggunakan metode net, sehingga membuat Rumah Sakit menanggung pajak karyawannya. Denagan menggunakan metode Gross, Rumah Sakit XYZ bisa terhindar dari keterlambatan penyetoran pajak. Sehingga kewajiban kontijensi bisa dihindari oleh Rumah Sakit XYZ. Selain itu, pegawai di bagian pajak harus benar-benar mengontrol agar kewajiban perpajakan harus dilakukan sesuai dengan peraturan yang ada.

\section{REFERENSI}

Andini, Luh Gita \& I Kadek Sumadi. 2014. Analisis Penerapan Tax Review Atas Pajak Penghasilan Badan dan Withholding Tax Pada Hotel X. EJurnal Akuntansi Universitas Udayana. 9.1 (2014), ISSN 2302-8556. Pp: 69-87.

Ayuningsih SR, Setiawan PE. 2016. Penerapan Tax Review Atas Pajak Penghasilan Badan Dan Withholding Tax Pada PT. ABC. E-Jurnal Akunt. Univ. Udayana 16: 2480-2506.

Dalughu Meyliza, (2015), Analisis Perhitungan Dan Pemotongan PPh Pasal 21 Pada Karyawan PT BPR Primaesa Sejahtera Manado, Jurnal Berkala Ilmiah Efisiensi. Volume 15 No. 3 Tahun 2015.

Dewi, A.A. Istri Shintia \& Putu Ery Setiawan. 2015. Penerapan Tax Review Atas Pajak Penghasilan Badan Sebagai Dasar Evaluasi Kewajiban Perpajakan. E-Jurnal Akuntansi Universitas Udayana Vol.13.No.2, ISSN 2302-8556. Pp: 513-531.

Frida Lingga. 2008. Penerapan Tax Review atas PPh 21 Tahun Pajak 2006 pada PT. "X". Skripsi Jurusan Akuntasi Fakultas Ekonomi Universitas Kristen Petra, Surabaya.

Goulding, Charles R. Sarbanes Oxley Acquisition Tax Due Diligence a New Tool for Analyzing Public Company Targets. The International Tax Journal, Fall 2005. Pp: 21-continue to 52.

Gunadi. 2004. Bunga Rampai Pemeriksaan Penyidikan \& Penagihan Pajak. Jakarta: Multi Utama Indojasa. 
Hadianto, Elvia Irawati. 2010. Penerapan Tax review Atas Kewajiban Perpajakan Pedagang Pengumpul PT X. Skripsi. Universitas Kristen Petra.

Homenta R. Herduard, (2015), Analisis Perhitungan, Pemotongan, Pencatatan, Dan Pelaporan Pajak Penghasilan Pasal 21 pada CV. Multi Karya Utama, Jurnal EMBA. Vol. 3 No. 3 September 2015, Hal. 916-926

Irawati. 2011. Kebijakan Pembayaran Dalam Perpajakan. Jurnal Kybernan Vol. 2 No 1, 2011. Pp: 60-67

James, Simon and Alley, Clinton. 2004. Tax Compliance, Self Assessment and Tax Administration. Journal Of Finance And Management In Public Servic, 2(2), Pp: 27-42

Knoll, Michael S. 2010. The Corporate Income Tax and the Competitiveness of U.S. Industries.Tax Law Review.Pp: 771-795.

Krupsky, Kenneth J. 2005. Withholding Tax on Interest Paid to US and UK."Financial Institution". Tax Management International Journal. Pp: 340-342.

Mardiasmo.(2016). Perpajakan Edisi Revisi.Yogyakarta: Penerbit Andi.

Oldani, Jessica L. 2012. Rehabilitating the U.S. Corporate Income Tax System in Light of Current Realities and 26 U.S.C. $§ 965$. The International Lawyer. Pp: 709-740

Peraturan Direktur Jenderal Pajak Nomor PER-16/PJ/2016 tentang Pedoman Teknis Tata Cara Pemotongan, Penyetoran, dan Pelaporan PPh Pasal 21/26 Sehubungan dengan Pekerjaan, Jasa, dan Kegiatan Orang Pribadi

Republik Indonesia. 2008. Undang-Undang Nomor 36 tentang Perubahan Keempat Atas Undang-Undang Nomor 7 Tahun 1983 tentang Pajak Penghasilan.

Republik Indonesia. 2009. Undang-Undang Nomor 16 tentang Perubahan terakhir kali atas Undang-Undang Nomor 6 Tahun 1983 tentang Ketentuan Umum dan Tata Cara Perpajakan (KUP).

Resmi, Siti. 2011. Perpajakan : Teori dan Kasus. Jakarta : Salemba Empat.

Salim, Tienneke. 2010. Penerapan Tax review Atas Perhitungan Pajak Penghasilan (PPh) Badan Sebagai Dasar Evaluasi Pemenuhan Kewajiban Perpajakan Pada PT X. Thesis. Universitas Kristen Petra.

Setiawan, Agus. \& Musri, Basri. 2007. Tax Audit dan Tax Review. Jakarta: PT Raja Grafindo Persada.

Sugiyono. 2013. Metode Penelitian Bisnis Kuantitatif Kualitatif \& RND. Bandung: Alfabeta.

Susan Jeane. (2013). Analisis Perhitungan Pajak Penghasilan Pasal 21 pada PT. Megasurya Nusalestari Manado, Jurnal EMBA. Vol. 1 No. 4 Desember 2013, Hal. 1599-1607

Villios, Sylvia. 2011. Australia: Impact of Tax Review Report and the Henry 
Ni Made Tika Anggreni dan Naniek Noviari. Analisis Pelaksanaan Kewajiban Atas....

Zahroh, Ahmad Abu dkk. 2016. Penerapan Tax Review Atas Pajak Penghasilan Dan Withholding Tax (Studi Kasus Pada PT. Asika Karya Mandiri). Equity Universitas Bhayangkara Surabaya. 